\title{
Knowledge of HIVIAIDS and the Use of Contraceptives (Condom) as Prevention Among Students of Federal College of Education, Kontagora, Niger State
}

\author{
Aliyu Mohammed ${ }^{1,}$, , Oyerinde Olufemi Oyesegun ${ }^{2}$ \\ ${ }^{1}$ Department of Physical and Health Education, Federal College of Education, Kontagora, Nigeria \\ ${ }^{2}$ Department of Human Kinetics and Health Education, Bayero University Kano, Kano, Nigeria \\ Email address: \\ muhammedaliyu503@gmail.com (A. Mohammed) \\ ${ }^{*}$ Corresponding author
}

\section{To cite this article:}

Aliyu Mohammed, Oyerinde Olufemi Oyesegun. Knowledge of HIV/AIDS and the Use of Contraceptives (Condom) as Prevention Among Students of Federal College of Education, Kontagora, Niger State. International Journal of HIV/AIDS Prevention, Education and Behavioural Science. Vol. 5, No. 2, 2019, pp. 105-109. doi: 10.11648/j.ijhpebs.20190502.14

Received: July 22, 2019; Accepted: September 2, 2019; Published: September 16, 2019

\begin{abstract}
The study investigates the knowledge of HIV/AIDS and the use of contraceptive among the students of Federal college of Education, Kontagora. The subject of study were randomly selected. Sample of 300 students were used for the study. The instruments use for the study was questionnaire validated and tested for reliability. Data collected were analyzed using Pearson Product Moment Correlation Coefficient and t-test as appropriate. The finding revealed that there was significant relationship between the student's knowledge and other sexual transmitted diseases. There was significant different between the student knowledge of HIV/AIDS and the use of condom as preventive devices. There was significant difference between student knowledge and other sexually transmitted diseases. There was significant difference between the student knowledge of mode of transmission of HIV/AIDS and other STDS among students of Federal college of Education, Kontagora. The student's knowledge of contraceptive had no significant relation to the knowledge of contraceptive device. Based on these findings the following recommendations were made. AID Education should be incorporated in the school curriculum; also adequate information on knowledge of HIV/AIDS should be made available to the students of Federal college of Education, Kontagora through technology and health education.
\end{abstract}

Keywords: Contraceptives, Knowledge, Kontagora, Prevention, Students

\section{Introduction}

HIV/AIDS is an unprecedented public health problem facing the entire world. Confirmed cure is neither in sight nor reliable vaccine likely for several years thereby making the infection with HIV/AIDS an urgent problem worldwide and this has with medical, social and economic implications.

It has been noted that AIDs was first discovered in the USA in 1981 [1]. He further stressed that retrospective studies indicated that the first cases might have occurred there as early as 1978 . The geographical origins of the virus causing the diseases are not clear. However, it appears that this virus is the first of its kind in modern history that has spread wide among population [2].
Nigeria with about $2.5 \%$ of the world population, contributes approximately $10 \%$ of the global HIV burden. It is second only to South Africa in terms of global HIV burden $[3,4]$.

Orubuloye [5] emphasized that, in Nigeria, heterosexual intercourse is the predominant mode of transmission which account about $68.5 \%$ cases $[6,7]$ opined that adolescents are also a group of high risk in the rapidly growth of HIV/AIDS pandemic: This is because the adolescent age is a time of rapid growth and development. It is also time of sexual maturity and initiation sexual activities. These authors further said that during this period youth's health to control their lives and make independent decisions. They try our experiences for the first time and this is often the time for sexual experimentation by some youths. It often, however, 
accompanied by lack of knowledge and skills to make healthy choices. Another group at risk of HIV/AIDS infection includes high-risk individuals, such as STD patients are useful since the related counseling may change their behavior and keep them free of HIV infection with STD [8].

Nigerian young women are 2-5 times at a higher risk of contracting HIV than their male counterpart.[9]. The female preponderance compared to the general Nigerian population may also be the result of the effect of sex on health seeking behavior. It is a well-known fact that females have a better health seeking behavior and thus are more likely to seek help much earlier compared to males [10].

So also, studies from the world have formed the association between both ulcerative and inflammatory STDS and HIV/AIDS, suggesting a role STDS play in amplifying the risk of infection with HIV/AIDS. Recurrent hepetic ulcers and other genital lesions have been shown to facilitate transmission of HIV/AIDS. Mother-to-child transmission (MTCT) is another way, which requires an urgent attention. Mother-to-child transmission is responsible for $5-10 \%$ if the total new HIV infection each year in many developing countries, with more than 500,000 children being infected each year. The furthermore said that antenatal care provided an opportunity to screen for illness and pregnancy complications and to treat the existing illness, when may affect the mother and the child. This makes imperative, research in to the ways which HIV can be contracted.

Contraception has globally become one of the most potent phenomena in reproductive health issue. Treacle [11] saw contraceptives technology as a medical success story for women who should not become pregnant because of medical problems. Contraceptives save lives and prevent morbidity and for the married user, contraception enhances quality of life, allowing couples to choose when they wish to have children. And for the teenagers and other unmarried users, it provides protection against unintended pregnancy and sexually transmitted diseases (STDS).

The Nigerian adolescent, like their counter parts in other parts of the world have become more sexually active. Studies have shown that the Nigeria adolescent initiate sexual activities quite early and remain sexually active for most of their adolescent years [12]. The resultant effect of this sex boon include increased rate of unintended pregnancy and sexually transmitted diseases. The fears of population explosion and death as a result of incurable STDS has stepped-up campaigns on the 23 contraceptives. Most teenagers all over the world are significantly becoming sexually active and must be provided with the means to protect themselves against pregnancy and transmitted diseases. They reported that in 1988 about 50\% American female adolescents and $60 \%$ male adolescents of 15 to 19 years had engaged in sexual experience and contacted sexually transmitted diseases. Contraceptives education will be used to create awareness about the use, efficiency and side effect, available birth control methods like pills, male condom, spermicidal form, injection, rhythm, withdrawal, abstinence, and other related method.
The federal college of Education Kontagora Youths represent a uniformed, cohesive and sexually active group expected to understand and utilize contraceptive education.

The purpose of this study was to:

i. provide student in higher institutions with special reference to Federal College of Education, Kontagora, Niger state with some basic information on the historical background, existence, danger, nature, course, control and prevention of HIV/AIDS.

ii. show clarity the mode of transmission of HIV/AIDS as against other STDS.

iii. examine the use of contraceptives devices e.g Condom, L.U.C.D and other methods of preventing unwanted pregnancy and HIV/AIDS.

In the light of the present investigation, the following hypotheses were formulated and tested;

i. There is no significant relationship between the knowledge of HIV/AIDS and the use of contraceptives as a method of prevention among Federal College of Education Kontagora.

ii. There is no significant difference between the background knowledge of HIV/AIDS and other sexually transmitted diseases among students Federal College of Education Kontagora.

iii. There is no significant difference between the knowledge of mode of transmission of HIV/AIDS and other STDS among students of Federal College of Education, Kontagora.

iv. There is no significant difference between knowledge of contraceptive devices among students of federal college of education, Kontagora

\section{Research Methodology}

The study is a descriptive research design which made use of survey method. The sample consist of three hundred (300) male and female students thereof Federal College of Education Kontagora, Niger State. Simple random sampling and stratified sampling technique were used in the selection the subjects from parts I, II, and III to have a fair representation of students in each parts, the target population is (part II) and III consisting of 250 student randomly selected. The part I students are new in the school and are left with 50 , that is $25 \%$ of 700 students in the final year (part III) which is (175) and 25\% 500 students in part II students (125).

The main instrument was structured questionnaire, which was used to elicit the information from the respondents. The questionnaire consisted of 37 items and 6 sections A, B, C, D, $\mathrm{E}$ and $\mathrm{F}$.

A. Consist of information on personal data, (age, religion, sex, and marital status)

B. Information on knowledge of HIV/AIDS

C. Mode of transmission, prevention and control

D. Contraceptive on human health and

E. Type of contraceptives 
Descriptive statistic and inferential statistic such as test and Pearson product moment correlation were used to analyze the data collected. The alpha level set at 0.05 .

\section{Result and Discussion}

With the presentation of data and findings of this study, the study involve a total of 300 N.C.E. students of Federal college of Education, Kontagora, Niger state, the students that anticipated in the study $50.70 \%$ were male, while 49.305 were female.

H01: There is no significant Relationship between student's knowledge of HIV/AIDS and the use of contraceptives (condom) using Pearson product moment correlation coefficient.

Table 1. Relationship between Students Knowledge of HIV/AIDs and use of contraceptives.

\begin{tabular}{|c|c|c|c|c|c|c|c|}
\hline Variable & Cases & $\mathbf{X}$ & SD & DF & R-cal & R-crit & Decision \\
\hline Knowledge of HIV/AIDS & 300 & 14.7 & 1.5 & & & & \\
\hline Significant use of contraceptives (condom) as preventive & 300 & 13.6 & 1.58 & 598 & 0.48 & 0.164 & Sig. \\
\hline
\end{tabular}

Sig.-Significant

The result presented in table 1 above revealed that there was a significant relationship between the knowledge of HIV/AIDS and the students use of contraceptive (condom) as preventive method ( $\mathrm{r}-0.164)$ at 0.05 level of significant the hypotheses is rejected.
H02: There is no significant difference between the background knowledge of HIV/AIDS and other sexually transmitted diseases among students Federal College of Education Kontagora.

Table 2. Differences in knowledge of students about HIV/AIDS and other sexually transmitted disease.

\begin{tabular}{llllllll}
\hline Variable & Causes & $\mathbf{x}$ & SD & DF & T-cal & T-crit & Decision \\
\hline Knowledge of HIV/AIDS & 300 & 14.23 & 1.32 & & & & \\
& & & & 598 & 8.51 & Sig. & \\
Knowledge of STDs & 300 & 14.15 & 1.6 & & & & \\
\hline
\end{tabular}

Sig. - Significant

From the table 2 above, there was a significant difference between student's knowledge of HIV/AIDS and their knowledge on other sexually transmitted diseases (tcalculated value of 8.51 at 0.05 alpha were obtained) the hypothesis was rejected.
H03: There is no significant difference between the knowledge of mode of transmission of HIV/AIDS and other STDS among students of Federal College of Education, Kontagora.

Table 3. Difference in knowledge of students about the mode of transmission of HIVIAIDS and other STDs.

\begin{tabular}{|c|c|c|c|c|c|c|c|}
\hline Variable & Causes & $\mathbf{x}$ & SD & DF & T-cal & T-crit & Decision \\
\hline \multirow[t]{2}{*}{ Knowledge of mode of transmission of HIV/AIDS } & 300 & 13.34 & 1.45 & & & & \\
\hline & & & & 598 & 4.20 & 2.58 & Sig. \\
\hline Knowledge of mode of transmission of STDs & 300 & 14.15 & 1.6 & & & & \\
\hline
\end{tabular}

Sig.-Significant

Table 3: From the table above, it was revealed that there is no significant difference between the students' knowledge of mode of transmission of HIV/AIDS and other mode of transmission of STDS in Federal College of Education, Kontagora because, calculated is 4.20 of 0.05 alpha level of significant and t-critical is 2.58 , re-calculated is 2.58 greater than critical, the hypotheses is rejected.

H04: There is no significant difference between knowledge of contraceptive devices among students of federal college of education, Kontagora.

Table 4. Relationship between student's knowledge of contraceptives and contraceptive devices.

\begin{tabular}{|c|c|c|c|c|c|c|c|}
\hline Variable & Causes & $\mathbf{x}$ & SD & DF & R-cal & R-crit & Decision \\
\hline Knowledge of HIV/AIDS & 300 & 1.100 & 0.63 & & & & \\
\hline Knowledge of contraceptive devices & 300 & 14.720 & 1.50 & 598 & 0.0023 & 0.254 & NS \\
\hline
\end{tabular}


Table 4 above that there was no significant correlation in student's knowledge of contraception and contraceptive devices, since re-calculated is 6.023 and critical is 0.254 at alpha level 0.0005 . Therefor the hypotheses is not rejected.

\section{Discussion of the Findings}

The findings that there was a significant relationship between the students awareness of HIV/AIDS and the use of contraceptive (condom) as prevention was not surprising considering the amount of propagation mounted by the W.H.O governments and Non-Governmental organization to educate the people about AIDS- causes, sign and symptoms and prevention. For example, World Health Organization assembly, 1987, sent information to the world revealing HIV as a natural accruing retrovirus namely immune deficiency virus (types I and II or T-lymhotrophic virus III infection). Also, illicit sex without the use of condom accounted for millions on Nigerians being infected by AIDS making became pandemic.

Anworth reported that epidemic disease have been known to cause greater damage to several countries. This move gradually to different localities and other places [13]. No wonder, the awareness of HIeV/AIDS has reached the students, of federal college of education Kontagora and the need to use condom as preventive measures.

The findings that there was significant difference between student's knowledge of HIV/AIDS and that of other sexually transmitted diseases. A large number of alternative and books are available to students for use. Bowen [14] report that many authors said AIDS could become one of the worst health problems in the history of the world. Sexual exploitation by both young and old have contributed to this scourge. Also, world health organization (WHO) estimated that the number of people with STDS is increasing about 250 million a year. The impact of AIDS epidemic is particularly great because it affects mainly young ad middle age men and women in their most productive years resulting in the loss of income, decrease in the work force and loss of productivity resulting from the sick leave, disability and even death.

Students' knowledge about HIV/AIDS revealed that most blood transfused in our hospital were not screened for HIV/AIDS and other sexual transmitted diseases among students of Federal College of Education, Kontagora Niger State. AIDS is only possible of HIV infection is spread when the blood, semen or sperm (male seminal fluids) or virginal secretion of an infected person (carrier) come in contact with the blood or mucus membrane (and inner lining of the virginal, anus urethra). of a healthy person.

\section{Conclusion}

The findings revealed that there was no significant correlation between the student's knowledge of contraception and contraceptive devices as prevention. Martinez in their paper explained that teenagers, all over the world are significant becoming sexually active and must be provided with the means to protect themselves against pregnancy and sexually transmitted diseases and the fear of population explosion and death [15]. The students of Federal College of Education Kontagora, had no-significant relationship with contraception and contraceptive as prevention for HIV/AIDS and sexually transmitted diseases alone.

\section{Recommendations}

Based on the findings of this study, the following recommendations were made:

1. Adequate knowledge should be provided on information on HIV/AIDS and other sexually transmitted diseases (STDS), in Federal College of Education Kontagora.

2. Sex education should be given priority in our tertiary institutions especially colleges of Education.

3. The government should provide teachers who's major in sex education in our tertiary and most especially major in health education. These teacher should not emphasize one topic over the other so that a balanced knowledge of both HIV/AIDS and other sexually transmitted disease (STDS) will be maintained.

4. More emphasis should be given to health education or health sciences in our tertiary institutions.

5. The Federal College of Education, Kontagora authority should provide amenities for testing HIV/AIDS in the school community before admission.

6. The Federal College of Education, Kontagora should liaise with the Federal Ministry of Health for intensive campaign against HIV/AIDS through posters, handbills and mass media both printed and electronic through which the students could be adequately reach.

7. The students Affairs division of Federal College of Education, Kontagora should provide all the necessary information gargets that will enable them read and listen news all the time. Common room for students should be provided with television and radio.

8. The Federal College of Education, Kontagora authorities should provide contraceptives (condom) to the students freely.

\section{References}

[1] Mann, D. G. (1987). AIDS World Health Forum 8: 361-370. Nurse practitioners (1995), sexually transmitted disease and HIV infection. Clinicians Handbook of clinic and preventive services.

[2] Olaleye, O. D. (2000). The HIV/AIDS Player: A threat to continuous hurn-ri existence. A monthly guest lecture, faculty of ventinary medicine, university of Ibadan, Ibadan. March 29.

[3] UNAIDS (2006). Report on the global AIDS epidemic. Geneva. UNAIDS. 2006.

[4] National Agency for the Control of AIDS. (2014). Global AIDS Response Country Progress Report. Nigeria GARPR 2014. Federal Government of Nigeria. 
[5] Oruboloye L. O Caldwell J. C. Caldwell, P (1990). Changes in nature and levels of sexually networking in an African society: a destabilization of the traditional Yoruba system. Health Trans review: 5 , 35: 12-16.

[6] Fawole, O. L, Asuzu, M. C. \& Oduntan, O. (1999). Survey of Knowledge attitudes and sexual practices relating to HIV infections/AIDS among Nigerian secondary school students. African journal of reproductive Health 3: 16-23.

[7] Kresis, I. K, Koech, D. Plammer, F. A, Holmes, K. K. Light Foote, M., Poit, P. (1986). AIDS VIRUS infection in Nairobi Prostitutes New England Journal of medicine. 203: 314-418.

[8] Ezechi, O. C., David, A. N., Idigbe, I. E. \& Ohihoin, A. G. (2017). Behavioral and Sexual Practices of HIV Infected Southwestern Nigerians: Implications for HIV Prevention and Control in the Country. Journal of Prevention \& Treatment of HIV/AIDS. 2 (1). P. 1-5.

[9] Ramjee G, Daniels B. Women and HIV in sub-Saharan Africa. AIDS research and therapy. 2013; 10 (1).

[10] Wang Y, Hunt K, Nazareth I, Freemantle N, Petersen I. Do men consult less than women? An analysis of routinely collected UK general practice data. BMJ open. 2013; 3 (8).
[11] Treacle, T. (1995). Understanding the use of contraceptive unpublished. Asdminar paper.

[12] Adebusoye, P. U. (1992). Sexual Behavior, Reproductive Knowledge and Contraceptive Use Among Young Urban Nigerians. International Family Planning Perspectives. 18,(2) pp. 66-70 Published by: Guttmacher Institute DOI: 10.2307/2133396. https://www.jstor.org/stable/2133396.

[13] Anworth, M (1997). Confronting AIDS World Bank, 98/1513, 10F4. Best and Kahn 91989) understanding and research methodology U.S.A Oxford printing press.

[14] Bowen, O. (1987). The 20th Century player. England, Lion Publisher Plc.

[15] Martinez, G. M., \& Abma, J. C. (2015). Sexual activity, contraceptive use, and childbearing of teenagers aged 15-19 in the United States, Data Brief No. 209. National Center for Health Statistics. Retrieved from https://www.cdc.gov/nchs/data/databriefs/db209.pdf 